\title{
TEACHING EFFECTIVENESS OF UNIVERSITY TEACHER`S IN RELATION TO THEIR SENSE OF HUMOUR
}

Dr. Umender Malik, Assistant Professor, Dept. of Education, Maharashi Dayanand University, Rohtak , India

\begin{abstract}
The purpose of this study was to study the relationship between Teaching effectiveness and Sense of Humourof university teachers of Haryana state. The study was conducted on a sample of 200 University teachers from various universities situatedin Haryana state. Teacher effectiveness scale constructed by the investigator and Teacher's Sense of humour scale by Malik and Kapoor were used to asses Teaching effectiveness and Sense of humour of university teachers. Causal comparative method of research and Random sampling technique was used in the study. The result indicated that teachers with high sense of humour were found to be more effective teachers than with average sense of humour and low sense of humour. The study further reveals that female teacher's with high sense of humour had more teaching effectiveness as compared to female teachers with average sense of humour and low sense of humour whereas Male teachers with average sense of humour were found to be more effective teachers than male teachers with high sense of humour and low sense of humour. It also has been observed that there was positive correlation between Teaching effectiveness and Sense of Humour of University teacher`s. This was also supported by Sarita(2015) in her study on teaching effectiveness of secondary school teachers in relation to their Sense of Humour. Malik (2017) in his study "A study of Teaching effectiveness of secondary school teachers in relation to their sense of humour and socio-economic status" found a positive correlation of 0.199 between Teaching effectiveness and Sense of Humour.
\end{abstract}

KEYWORDS:Teaching effectiveness,Sense of Humour, UniversityTeacher's

Article Received: 10 August 2020, Revised: 25 October 2020, Accepted: 18 November 2020

\section{INTRODUCTION}

Professional is someone who has completed formal education and training in one or more profession.Teaching is also a Profession.Teacherare the heart of any educational system and the success of the institutionin the attainment of educational goals depends largely on the quality of the teachers. Teaching is considered to be one of the stressful professions specially because it involves daily work based on social interaction where the teacher must have to make efforts for establishing adjustment and also regulate not only his/her emotions but also those of students. In the era of Covid-19 pandemic teaching process has become more challenging and demanding.

\section{Teaching Effectiveness}

An effective teacher is described as one who is able to successfully perform tasks expected of him/her.Stronge et al (2004) stated that teaching is vocational and most effective teachers are passionate about their chosenprofession.Teaching effectiveness means the perfection,the optimum level of efficiency and productivity on the part of the teacher.Srivastava(2005) revealed that teaching effectiveness of male teachers dilutes with their increasing age and teaching effectiveness of female teachers increases to some extent with their age. Sharma (2019) in his study founded positive correlation between Teaching effectiveness and mood of class.

\section{Sense of Humour}

Humour is a social phenomenon that had been extensively explored through centuries, whereas sense of humour is an aspect of personality.Gorham(1999) revealed that amount and type of humour influence learning. Palmer (2020) in the study found significant difference in teaching effectiveness among secondary school teachers with sense of humour.

\section{Statement of the Problem}

Teaching effectiveness of University

teachers in relation to their Sense of Humour

\section{Operational Definitions of the Term Used}

Teaching Effectiveness

According to Ryan (1969), "An effective teacher may be understood as one who helps in development of basic skills, understanding proper work habits,desirable attitude,valuejudgement and adequate personality adjustment of the students'.Gupta (1984) defined teacher effectiveness as the capacity of a teacher to bring about the agreed change in his or her student. Operationally speaking in the present study teaching effectiveness of a teacher refers to the scores obtained by him on the Teacher Effectiveness scale. 


\section{Sense of Humour}

Sense of Humour is defined as a sort of catch -all term to refer to habitual individual differences in all sorts of behaviours,experiences,affects attitudes and abilities relating to amusement,laughter,jocularity and so on (Martin1998).Operationally speaking in the present study sense of humour refers to the score of a teacher-on-Teacher Sense of Humour Scale

\section{University Teachers}

The teachers who are teaching in the various universities main campus of Haryana are considered as University teachers.

\section{Objectives of the Study}

O1. To study teaching effectiveness of male and female university teachers of Haryana.

O2. To study teaching effectiveness of university teachers of Haryana in relation to their high sense of humour,average sense of humour and low sense of humour.

O3. To study teaching effectiveness of male university teachers of Haryana in relation to their high sense of humour,average sense of humour and low sense of humour.

O4. To study teaching effectiveness of female university teachers of Haryana in relation to their high sense of humour,average sense of humour and low sense of humour.

O5. To study the relationship between teacher effectiveness and sense of humour of university teachers of Haryana.

\section{Hypotheses of the Study}

Ho1. There is no significant difference in teaching effectiveness of male and female university teachers of Haryana.

Ho2. There is no significant difference in teaching effectiveness of university teachers of Haryana in relation to their high sense of humour,average sense of humour and low sense of humour.

Ho3. There is no significant difference in teaching effectiveness of male university teachers of Haryana in relation to their high sense of humour, average sense of humour and low sense of humour.

Ho4. There is no significant difference in teaching effectiveness of female university teachers of Haryana in relation to their high sense of humour, average sense of humour and low sense of humour.

Ho5. There is no significant relationship between teacher effectiveness and sense of humour university teachers of Haryana.

Variables in the Study

effectiveness
Independent Variable - Sense of Humour

\section{Design of the Study}

Causal Comparative method of research was used.

\section{Population}

A population is any group of individuals that have one or more characteristics common in the area of the interest to the investigator. It may be all the individuals of a particular type or a restricted part of that group (Best,1977).All the University teachers teaching in main campus of universities situated in Haryana state constitute the target population for the present study.

Sample

Measuring the entire population is impracticable,though not entirely impossible be drawn for the purpose. Therefore, a sample from the concerned population may be drawn for the purpose of data collection.In the present study Random sampling technique was used to select the sample of 200 University teachers.

Tools used in the Study

Teacher Effectiveness Scale (TES)

constructed by investigator

Teacher's Sense of Humour Scale (TSHS)

by Malik and Kapoor,2014

Delimitations of the Study

1. The study is delimited to 200 secondary

school teachers.

2. The study is delimited to only university teachers of Haryana State.

3. The study is delimited to only one Dependent variable i.e Teaching Effectiveness and one

\section{Statistical Techniques}

Independent variable i.e Sense of Humour

Mean, S.D. and t-test were used

\section{Analysis and Interpretation}

The collected data were analyzed both quantitatively as well as qualitatively.In order to verify the objectives and to test the null hypotheses, the present study has been analyzed as given below:

Objective 1: To study Teaching Effectiveness of Male and Female university teachers of Haryana.

For the purpose of studying the difference between teaching effectiveness of male and female university teachers the following null hypothesis was formulated.

Ho1 There is no significant difference in Teaching Effectiveness of Male and Female university teachers of Haryana.

To test the null hypothesis, Mean, Standard Deviation, $t$-value and level of significance of the scores obtained from teaching effectiveness scale was 
calculated with respect to gender. The results are

presented in Table 4.1.

Table 4.1: Mean, Standard Deviation and ' $t$ ' value of TeachingEffectiveness of Male and Female UniversityTeachers

\begin{tabular}{|l|l|l|l|l|l|l|}
\hline $\begin{array}{l}\text { Dependent } \\
\text { Variable }\end{array}$ & Gender & N & Mean & SD & 't' & $\begin{array}{l}\text { Level of } \\
\text { Significance }\end{array}$ \\
\hline $\begin{array}{c}\text { Teaching } \\
\text { Effectiveness }\end{array}$ & Male & 132 & 218.12 & 31.37 & \multirow{2}{*}{1.28} & Not Significant \\
\cline { 2 - 7 } & Female & 68 & 223.64 & 27.37 & & \\
\hline
\end{tabular}

$0.05 \leq 1.97,0.01 \leq 2.60$

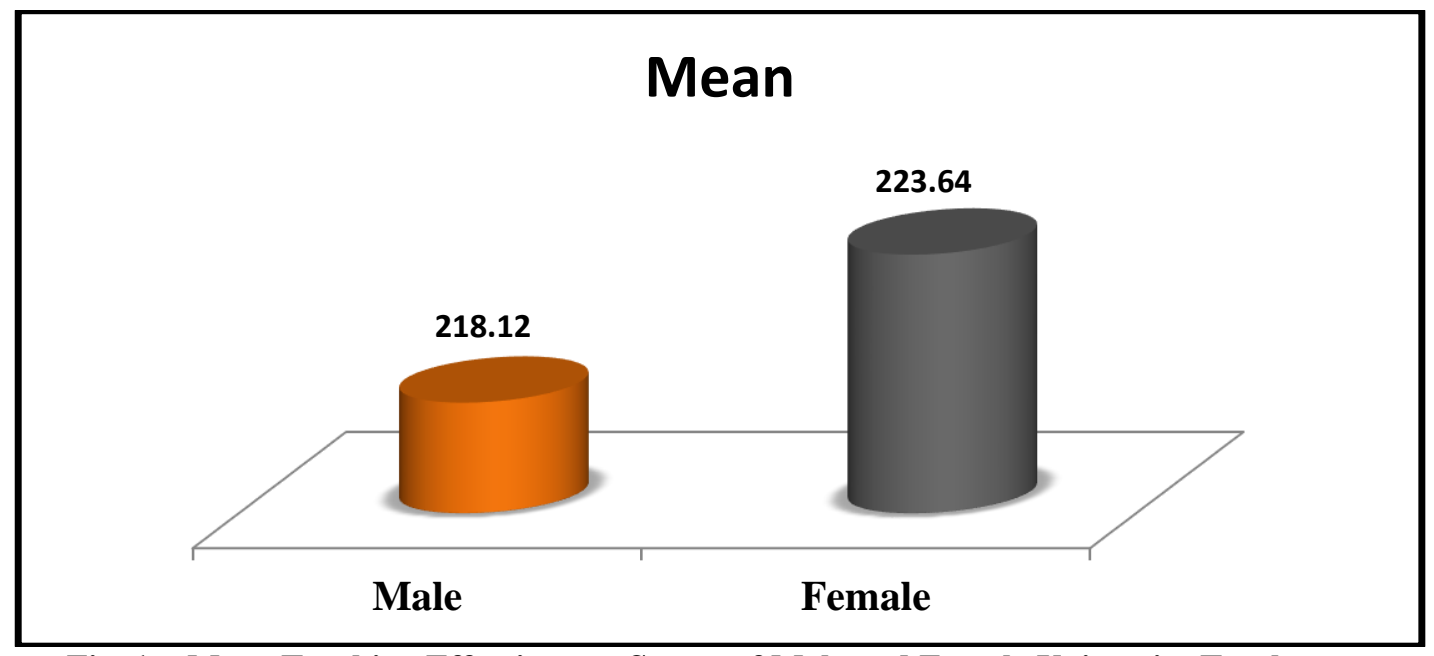

Fig. 1: Mean Teaching Effectiveness Scores of Male and Female University Teachers

It is inferred from Table 4.1 and Fig.1, it can be observed that the t-value of 1.28 was not found significant at 0.05 level which indicates that the teaching effectiveness of male and femaleuniversity teachers did not differ significantly. So, the null hypothesis i.e.there is no significant difference between the teaching effectiveness of male and femaleuniversity teachers, is accepted. So, it can be concluded that there is no significant difference in male and female regarding teaching effectiveness. The findings of the study is in contrast with the finding of Biswas et al. (1995) who found that male and female teachers differ significantly on teacher effectiveness. Further it has also been observed that the students at university level has attained that much age, which doesn't affect their learning on the basis of gender of a university teacher.

Objective 2: To study Teaching Effectiveness of university teachers of Haryana in relation to their High Sense of Humour, Average Sense of Humour and Low Sense of Humour.

Table 4.2

Mean, Standard Deviation and 't' value of TeachingEffectiveness of University Teachers with respect to their High Sense of Humour (HSOH), Average Sense of Humour (ASOH) and Low Sense of Humour (LSOH)

\begin{tabular}{|c|c|c|c|c|c|c|c|c|}
\hline $\begin{array}{l}\text { Dependent } \\
\text { Variable }\end{array}$ & $\begin{array}{c}\text { Groups of Sense } \\
\text { of Humour }\end{array}$ & & J & & an & & & $\begin{array}{c}\text { 't' } \\
\text { values }\end{array}$ \\
\hline \multirow{2}{*}{ 声 } & $\mathrm{HSOH}$ vs ASOH & 67 & 105 & 223.01 & 222.90 & 33.28 & 26.61 & $\begin{array}{l}0.022 \\
(\mathbf{N S})\end{array}$ \\
\hline & ASOH vs LSOH & 105 & 28 & 222.90 & 202.75 & 26.61 & 29.70 & $3.26 * *$ \\
\hline
\end{tabular}




\begin{tabular}{|l|l|l|l|l|l|l|l|l|}
\hline & LSOH vs HSOH & 28 & 67 & 202.75 & 223.01 & 29.70 & 33.28 & $2.92 * *$ \\
\hline
\end{tabular}

** Significant at 0.01 level,

$0.05 \leq 1.98,0.01 \leq 2.61$

* Significant at 0.05 level,

NS = Not Significant

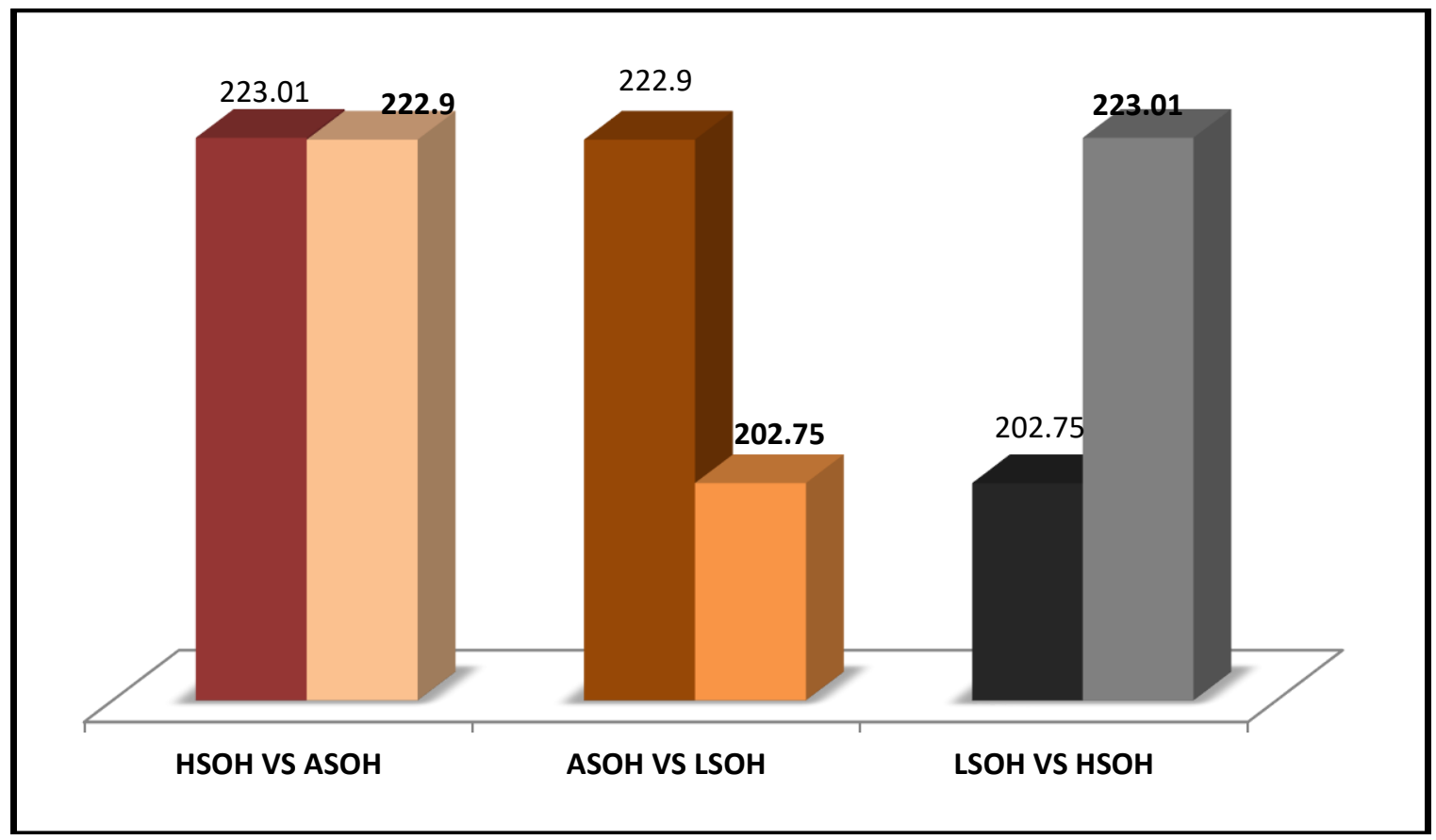

Fig. 2: Mean Teaching Effectiveness Scores of UniversityTeacherswith respect to their High Sense of Humour (HSOH), Average Sense of Humour (ASOH) and Low Sense of Humour (LSOH)

The mean teaching effectiveness score of university teachers with High Sense of Humour (223.01 \pm 33.28 ) is higher than teachers with Average Sense of Humour $(222.90 \pm 26.62)$, the ' $t$ ' ratio being not significant $(0.022)$ at 0.05 level of significance. It explores that teachers with High Sense of Humour are effective teachers than teachers with Average Sense of Humour.The mean score of teachers with Average Sense of Humour (222.90 \pm 26.62$)$ is lower than teachers with Low Sense of Humour (202.75 \pm 29.70$)$, the ' $t$ ' ratio being significant (3.267) at 0.01 level of significance. It explored that teachers with Average Sense of Humour are less effective teachers than teachers with Low Sense of Humour. Further the mean score of teachers with Low Sense of Humour $(202.75 \pm 29.70)$ is less than teachers with High Sense of Humour (223.01 \pm 33.28$)$, the ' $t$ ' ratio

Table 4.3

Mean, Standard Deviation and ' $t$ ' value of TeachingEffectiveness of Male University Teachers with respect to their High Sense of Humour (HSOH), Average Sense of Humour (ASOH) and Low Sense of Humour (LSOH)

\begin{tabular}{|l|c|c|c|c|c|}
\hline $\begin{array}{l}\text { Dependent } \\
\text { Variable }\end{array}$ & $\begin{array}{c}\text { Groups of Sense } \\
\text { of Humour }\end{array}$ & $\mathbf{N}$ & Mean & SD & $\begin{array}{c}\text { 't' } \\
\text { values }\end{array}$ \\
\hline
\end{tabular}

being significant (2.92) at 0.05 level of significance. It explored that teachers with HighSense of Humour are more effective teachers than teachers with Low Sense of Humour. These findings were supported by ShwetaKappor (2014), These result shows that individuals high in sense of humour often use humour as a way to charm and amuse others, ease tension among others and improve relationships. This helps them in maintaining a positive attitude even in trapping times.

Objective 3: To study Teaching Effectiveness of male university teachers of Haryana in relation to their High Sense of Humour, Average Sense of Humour and Low Sense of Humour. 


\begin{tabular}{|c|c|c|c|c|c|c|c|c|}
\hline \multirow{3}{*}{ 窇 } & $\mathrm{HSOH}$ vs ASOH & 53 & 64 & 218.84 & 221.89 & 35.17 & 27.73 & $\begin{array}{l}0.513 \\
\text { (NS) }\end{array}$ \\
\hline & ASOH vs LSOH & 64 & 15 & 221.89 & 199.53 & 27.73 & 26.74 & $2.89 * *$ \\
\hline & LSOH vs $\mathrm{HSOH}$ & 15 & 53 & 199.53 & 218.84 & 26.74 & 35.17 & $\begin{array}{l}2.29 \\
\text { (NS) }\end{array}$ \\
\hline
\end{tabular}

** Significant at 0.01 level,

$0.05 \leq 1.98,0.01 \leq 2.62$

* Significant at 0.05 level, NS = Not Significant

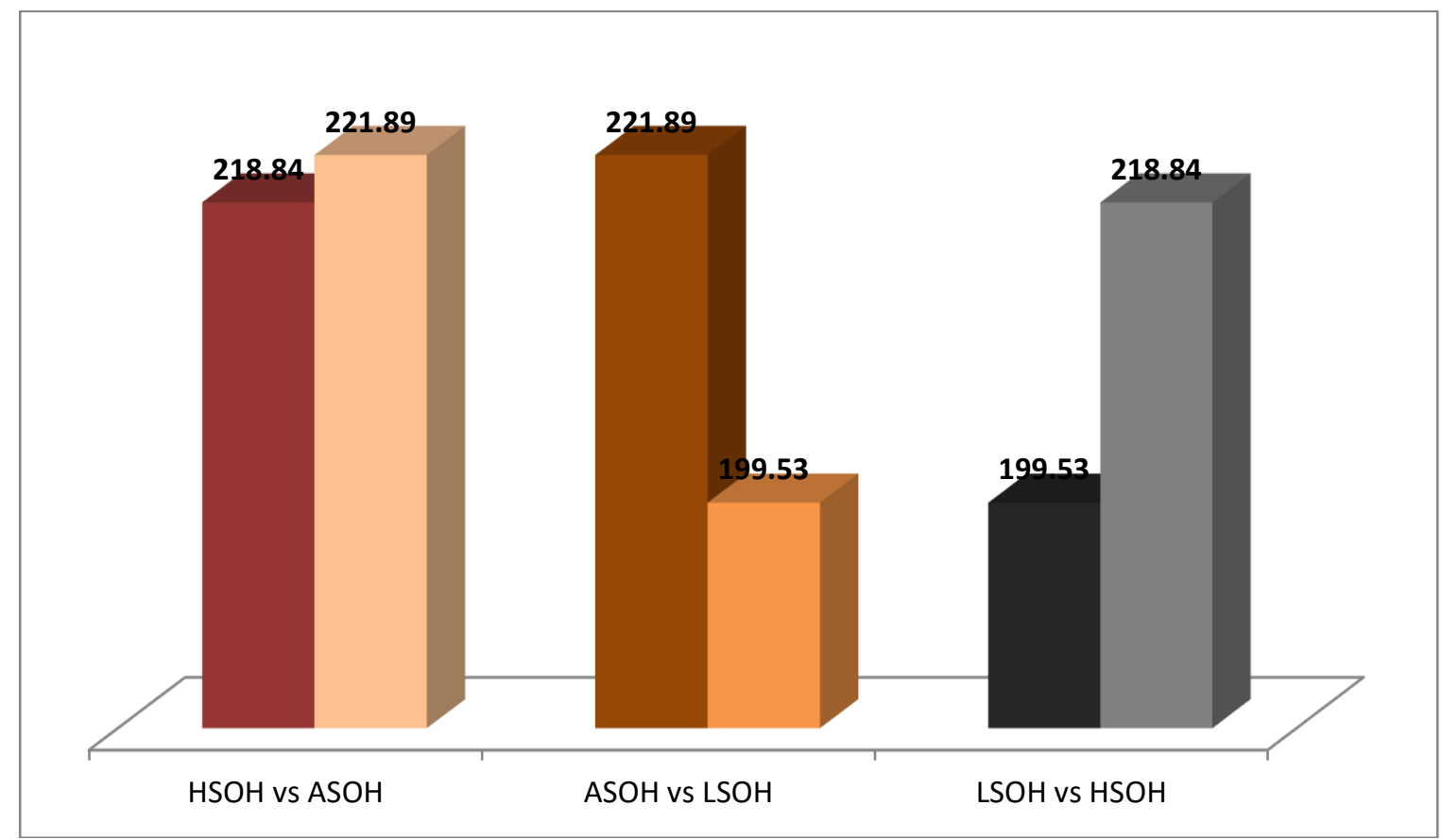

Fig. 3: Mean Teaching Effectiveness Scores of Male UniversityTeachers with respect to their High Sense of Humour (HSOH), Average Sense of Humour (ASOH) and Low Sense of Humour (LSOH)

The mean score of teaching effectiveness of male university teachers with High Sense of Humour $(218.84 \pm 35.17)$ is lesser than male teachers with Average Sense of Humour $(221.89 \pm 27.73)$, the ' $t$ ' ratio being not significant $(0.513)$ at 0.05 level of significance. It explores that teachers with High Sense of Humour are lesseffective teachers than teachers with Average Sense of Humour. The mean score of teachers with Average Sense of Humour (221.89 \pm 27.73$)$ is higher than teachers with Low Sense of Humour $(199.53 \pm 26.74)$, the ' $t$ ' ratio being significant (2.89) at 0.01 level of significance. It explored that teachers with Average Sense of Humour are more effective teachers than teachers with Low Sense of Humour. Further the mean score of teachers with Low Sense of Humour (199.53 \pm 26.74$)$ is less than teachers with High Sense of Humour $(218.84 \pm 35.17)$, the ' $t$ ' ratio being not significant (2.29) at 0.05 level of significance. It explored that male teachers with High Sense of Humour are more effective teachers than teachers with Low Sense of Humour.Male teachers deals with aesthetic enjoyment of incongruities, they see hilarity in circumstances and their quality of appreciation of fun helps them in making the teaching - learning environment more lively resulting in more effective teaching.

Objective 4: To study Teaching Effectiveness of female university teachers of Haryana in relation to their High Sense of Humour, Average Sense of Humour and Low Sense of Humour. 
Table 4.4

Mean, Standard Deviation and ' $t$ ' value of TeachingEffectiveness of Female University Teachers with respect to their High Sense of Humour (HSOH), Average Sense of Humour (ASOH) and Low Sense of Humour

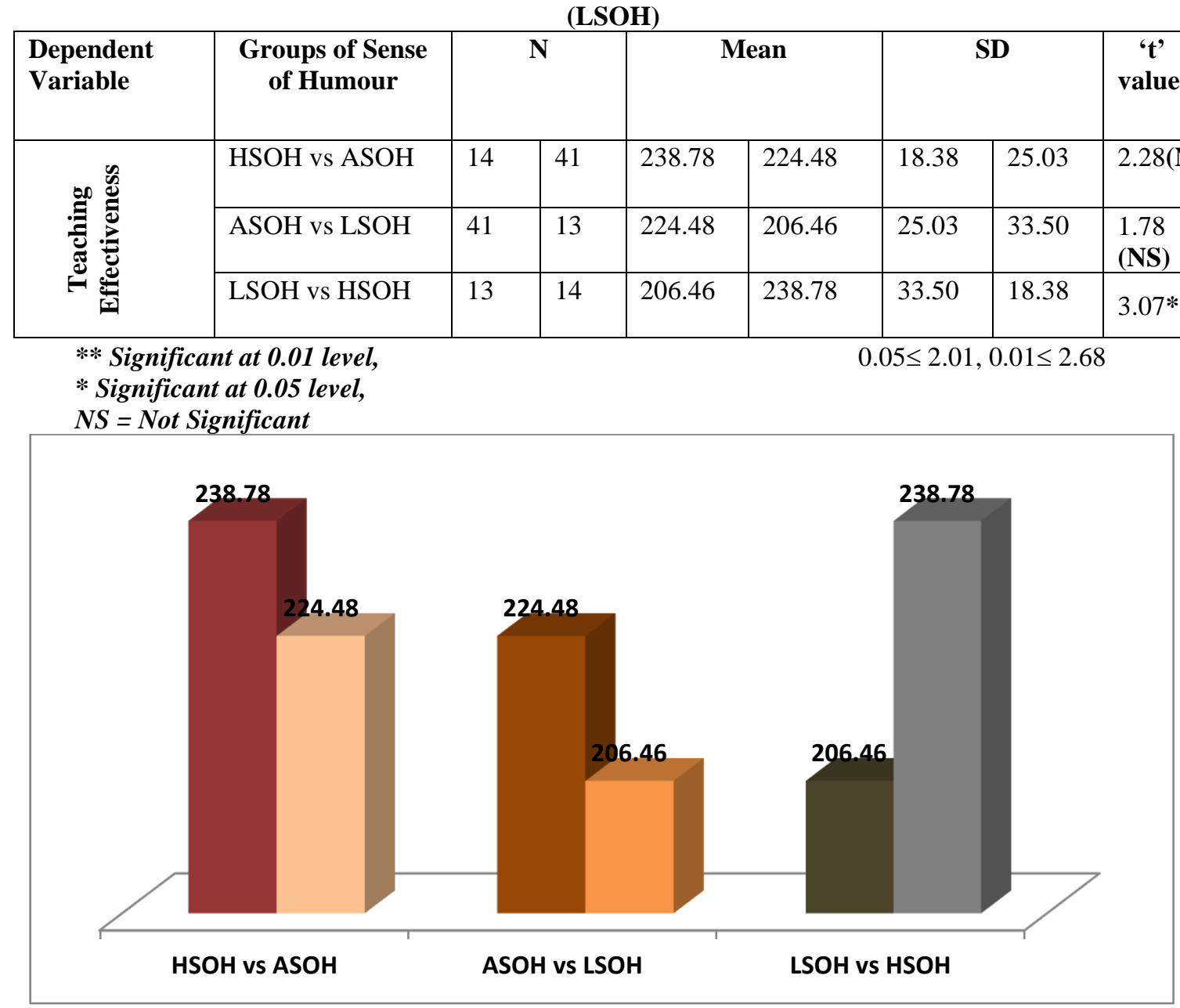

Fig. 4: Mean Teaching Effectiveness Scores of Female UniversityTeachers with respect to their High Sense of Humour (HSOH), Average Sense of Humour (ASOH) and Low Sense of Humour (LSOH)

The mean score of teaching effectiveness of female university teachers with High Sense of Humour $(238.78 \pm 18.38)$ is higher than teachers with Average Sense of Humour (224.48 \pm 25.03$)$, the ' $t$ ' ratio being not significant (2.28) at 0.05 level of significance. It explores that teachers with High Sense of Humour are more effective teachers than teachers with Average Sense of Humour. The mean score of teachers with Average Sense of Humour (224.48 \pm 25.03$)$ is higher than teachers with Low Sense of Humour $(206.46 \pm 33.50)$, the ' $t$ ' ratio being not significant (1.78) at 0.05 level of significance. It explored that teachers with Average Sense of Humour are more effective teachers than teachers with Low Sense of Humour. Further the mean score of teachers with Low Sense of Humour $(206.46 \pm 33.50)$ is less than teachers with High Sense of Humour (238.78 \pm 18.38$)$, the ' $t$ ' ratio being significant (3.07) at 0.05 level of significance. It explored that female teachers with High Sense of Humour are more effective teachers than teachers with Low Sense of Humour. It shows that female teachers with high sense of humour use positive styles of humour in class room which increases teaching effectiveness.

Objective 5: To study the relationship between teacher effectiveness and sense of humour of university teachers of Haryana.

Ho5 $_{05}$ There is no significant relationship between teacher effectiveness and sense of humour of university teachers of Haryana.

In order to test the null hypothesis, "There is no significant relationship between teacher effectiveness and sense of humour of university teachers of Haryana." The analysis is given below in the table.In pursuance of the objective stated above the coefficient of correlation was computed. 
Table 4.5

Coefficient of correlation (r) between Teaching Effectiveness and Sense of Humour of University Teachers

\begin{tabular}{|l|c|c|c|c|}
\hline Sr. No. & Variables & N & $\begin{array}{c}\text { 'r' } \\
\text { Value }\end{array}$ & $\begin{array}{c}\text { Level of } \\
\text { significance }\end{array}$ \\
\hline 1 & Teaching Effectiveness & 200 & 0.124 & \\
\hline 2 & Sense of Humour & 200 & \\
\hline
\end{tabular}

It is observed from the table 4.5 that the computed value of co-efficient of correlation between teaching effectiveness and sense of humour of university teachers is 0.124 which is not significantat 0.05 level of significance. Hence, the null hypothesis of no significant correlation between teaching effectiveness and sense of humour of universityteachers is accepted. It can be interpreted that teaching effectiveness and sense of humour of university teachers are positively correlated with each other.In simple words if the sense of humour of university teachers will be increase, the teaching effectiveness of university teachers will also be increase. Teachers with high sense of humour use affilativehumourfor maintaining a rapport with students. They further always try to look on the bright side of bad situations and maintain positive attitude.

Educational Implications Institutions should try to enhance use of humour in day today teaching -learning process. With use of humour anxiety and stress are decreased and that contribute to class unity and learning. It is often identified as teaching technique for developing a positive learning environment, (Fergurson\&Campinha -Bacote,1989; Walter,1990). Humour should be an integral part of the classroom teaching.

\section{WORK CITED}

Aggarwal, S. (2012). Correlational Study of Teaching Effectiveness and Job Satisfaction of Higher Secondary School Teachers. EduTracks, 12(2), 38.

Chi, Law Ning ( 1992). Humour and Teacher Burnout The Chinese University of Hong Kong Graduate School - Division Of Education Master of Arts in Education Thesis.

Dunkin, M. (1997). Assessing Teachers' Effectiveness. Issues in Educational Research 7(1).

Gillian A. Kirsh and Nicholas A. Kuiper (2003). Positive and negative aspects of sense of humour: associations with the constructs of individualism and relatedness. Humour-
$0.05 \leq 0.138,0.01 \leq 0.181$

international journal of humour research, $16(1)$.

Good, C.V. (1959). Dictionary of Education. 2/e,

New York:McGraw Hill and Co

Kaur, S. (2020).Correlates of Teacher Effectiveness. Patiala: 21st Century Publications.

Kher, N., Molstad, S. and Donahue, R.( 1999). Using humor in the college classroom to enhance teaching effectiveness in dread courses. College Student Journal, 33, 400405.

Kumar, Mutha (1974). Manual for Teaching Effectiveness, National Psychological corporation, Agra

Makewa, Role \& Genga (2019). Teachers' Use of Humor in Teaching and Students' Rating of Their Effectiveness. International Journal of Education, 3(2),8.

Malik, U. and Kapoor, S. (2014). Manual for Sense of Humour, National Psychological corporation, Agra.

Michael G. Lovorn (2008). Humor in the Home and in the Classroom: The Benefits of Laughing While We Learn. journal of education and human development, 2

P Malik(2014).Study of Teaching Effectiveness in relation to their Gender and Locality.International Educational EJournal 3(2), 193-197,2014

Raja, B., William, D. and Thiagarajan, A.P. (1998). Teacher-Effectiveness and School Organizational Climate of Boys' Higher Secondary Schools in Tuticorin. Sixth Survey of Educational Research 1993-2000. National Council of Educational Research and Training, New Delhi.

Sarita (2015).Teaching effectiveness of secondary school teachers in relation to their Sense of Humour.Global Journal for Research Analysis 4(07),48-49,2015

U Malik(2016).A study of occupational stress among secondary school teachers in relation to 
their Sense of Humour. Paripex -Indian journal of Applied Research, vol 4,( 11),2015.

U Malik(2017) .A study of Teaching Effectiveness of secondary school teachers in relation to

their Sense of Humour and Socio-economic status. Educational Quest 8(3),789-792,2017

Wrench \& Richmond (2004). Understanding the Psychometric Properties of the Humour

Assessment Instrument through an Analysis of the Relationships between Teacher

Humour Assessment and Instructional

Communication Variables in the college Classroom, 21(1), 92-103. 